\title{
Assembling governance: the role of standards in the Tanzanian tea industry
}

\begin{abstract}
Governing through standards has gained significant academic traction, particularly through discussions of global value chains and instruments of neoliberal private authority. Drawing from ethnographic work, I utilize examples from the tea industry in Tanzania to characterize the pragmatic nature of how standards govern at a distance in local contexts. These examples are the: 1) use of Fairtrade funds to fulfill community obligations; 2) participation in value chain actors’ bids for external technical assistance; and 3) participation in donor-funded projects unrelated to standards schemes, yet enable compliance with certification requirements. The analysis reveals that the nature of these programs is a combination of historically entrenched systems and neoliberal approaches to development. By conceptualizing these standards as agencements, rather than instruments of private regulation, we are able to better capture governmentality in the Foucauldean sense - as the mobilization of standards to provide public goods is a mode of governing that necessarily involves far more actors than the State alone.
\end{abstract}

KEYWORDS: Standards; certification; governmentality; agencement; corporate social responsibility; tea; Tanzania 


\section{INTRODUCTION}

As supply chains extend their reach across geographical and cultural space, they are increasingly becoming a dominant approach through which private and civic actors can 'govern at a distance' (Busch, 2007; Miller and Rose, 1990). This idea of 'governing through standards' refers to the ways in which a range of different standards are used to coordinate actors and to influence change in agri-food systems (Alphandéry et al., 2012; Ponte et al., 2011). This phenomenon is not new. More than ten years ago scholars commented on the dominance of retailer standards in governing food quality and safety (e.g.,Dolan and Humphrey, 2000), while even before this social and environmental movements sought change through the market (e.g., Taylor, 2005). Over the years, practitioners, donors, activists, and academics alike have been intrigued by the possibility, and often the impossibility, of this particular form of private governance to reshape the dynamics of globalization (Blowfield and Dolan, 2008; GTZ, 2006). However, the globalization of agri-food systems is both a transnational and a local issue (Bonanno and Constance, 2009). Therefore, we must ask: how do standards 'govern at a distance' in specific locales?

Since the early 1990s, tea estates in Tanzania have been certified for voluntary standards, with the increasing occurrence of multiple certifications. The standards in use are the Ethical Tea Partnership (ETP), Fairtrade International (FLO), the European Organic standards (EC834/2007 and EC889/2008; OR), and Rainforest Alliance (RA). Given the geographic and social organization of tea estates in Tanzania, tea companies have historically taken responsibility for providing local and district level development services such as roads, schools and hospitals. In recent years, certified estates have also been the recipients of other donor-funded projects. The complex and overlapping nature of these multiple 'responsibility' arrangements provides an opportunity to explore the local and institutional dynamics of standards and how they 'touch down' in the local setting. Increasing our understanding of these dynamics can contribute to debates over the potential and inherent limitations of private governance (Mayer and Gereffi, 2010; Ponte et al., 2011). 
Based on data collected ${ }^{1}$ through interviews (78), focus groups (21), observations in Tanzania, Kenya, Germany and the UK, and analysis of official policy and public corporate documents between 2008 and 2010, ${ }^{2}$ this case study reveals an interesting dynamic around private governance in Tanzania as tea estates are expected to provide a number of local social services that are often considered to be public goods. However, neither the companies nor the district governments always have the funds available to supply these services. Therefore, what we see emerging is a case where estates are pragmatically leveraging their affiliation with voluntary standards networks; in other words, creating agencements. By examining these different ways in which estates engage with standards networks and development projects, we can achieve a better understanding of how standards govern interactions in local contexts. I will show that standards govern not by enforcing rules as much as by facilitating the emergence of agencements, whereby a range of actors and devices are brought together in order to achieve both global and local objectives.

The chapter is organized in three main sections. First, I develop a conceptual framework for analysis that builds on theories of standards and private governance. Second, I contextualize the cases of Tanzanian tea estates within national social and political institutions. I then describe the three ways in which standards are mobilized in Tanzanian tea producing districts, which are: 1) to utilize the FLO social premiums to fulfill community obligations; 2) to be part of value chain partners' bids for technical assistance that improve performance on the standards' environmental criteria; and 3) to be part of other donor-funded development projects that are not related to their certification status - yet allow them to meet the requirements of certification. I conclude with reflections on how envisioning standards as agencements might contribute to better grasping these pragmatics of governance.

\section{FROM PRIVATE REGULATION TO AGENCEMENTS}

\footnotetext{
${ }^{1}$ The data used in this paper was collected as part of a larger study that examined the performance of the values of sustainability, corporate social responsibility and gender equity in tea value chains originating in Tanzania. Interviews were conducted in either English or Swahili by the author and were recorded when feasible. When audio recording was not feasible, notes were taken during the interview. The Swahili interviews were transcribed in full and translated, while only heavily coded passages were transcribed from the English interviews. Analysis was completed using Nvivo software. All interviews were conducted by informed consent and confidentiality was ensured.

${ }^{2}$ Ten repeat interviews and two new interviews were conducted in March 2014.
} 
Over the last twenty years a number of voluntary, general and industry codes and principles of practice have taken the form of multi-stakeholder initiatives (cf. Prakash and Potoski, 2006). These initiatives are described as mechanisms whereby “Non-governmental organizations [NGOs], multilateral and other organizations encourage companies to participate in schemes that set social and environmental standards, monitor compliance, promote social and environmental reporting and auditing, certify good practice, encourage stakeholder dialogue and 'social learning'” (Utting, 2002: 61). A number of approaches have developed over the years to try to explain the emergence of these initiatives according to how public, private and civic actors engage standards.

\section{Insights from private regulation and global value chains}

Regulation scholars understand these initiatives as forms of 'private regulation', which offer an alternative form of governance based on the enforcement (both positive certification and negative sanctions) of standards (e.g., Bernstein, 2011; Bernstein and Cashore, 2007; Büthe, 2010; Dingwerth and Pattberg, 2009). This approach takes the state as its point of departure and examines the responses of corporations and social movements to state deregulation. The above mentioned scholars claim that the neoliberal institutional context explains the states' failure to address serious ecological and social problems (e.g., Bartley, 2003). Here, the state is complicit and "through the ideology of deregulation, has stimulated market competition and privateinterest forms of regulation" (Marsden et al., 2000: 4). As a result, private companies and NGOs seek private avenues (through global markets) to gain authority for achieving these aims (Bernstein and Cashore, 2007). However, as research advances in this field there is increasing recognition of the hybridity of these governance relations where the public and civic sectors are re-emerging in new ways through the processes of globalization (SKASC, 2012). This requires recognition of the limits of the notion of 'private governance' and a refocusing of attention towards how public institutions interact with private governance (Mayer and Gereffi, 2010).

Analysis of the governance of global value chains (GVC) traditionally approaches the issue of standards from the analysis of private actors, focusing on how these actors govern transactions and coordinate actors in the chain (Bair, 2009; Gereffi et al., 2005). A number of scholars look at how power is exerted by lead actors in the chain, including the possibility for other actors, such as NGOs, consumers and unions, to influence governance patterns (Gibbon 
and Ponte, 2005; Lockie and Kitto, 2000; Riisgaard, 2011). This has opened the doors to analysis that focuses on 'twin-driven' governance (Islam, 2008) and horizontal governance (Tallontire et al., 2011) where stakeholders in supplier countries are recognized as exerting more influence than traditionally believed in supply chain negotiations. Recent advances in GVC analysis try to bring national and local institutional contexts into the analysis of how power relations change the supply chain (e.g., Neilson and Pritchard, 2009; Ouma, 2010; Rainbird and Ramirez, 2012). Here GVCs are seen as being "defined by a series of struggles which result in the co-production of governance structures and evolving institutional environments" (Neilson and Pritchard, 2009: 232). These authors propose that social and cultural institutions, which condition organizational forms and power relations, must also be taken into account.

The focus of the above literature is on the actors involved in governance through standards and on how they exert their power to influence others, mostly through the idea that the governing power of standards comes from the ability to make rules that others must follow (Abbott and Snidal, 2009), be they in the form of compliance with standard criteria or through the performance of their values (Gibbon and Ponte, 2008; Loconto, 2010, 2014). As illustrated, these approaches pose questions about what happens to the ability of standards to exert governing power when there is increased interaction between public and private actors in specific institutional contexts. However, as Neilson and Pritchard (2009) rightly point out, the power of institutions, and I would argue the standards themselves, are often discussed in terms of a backdrop and not in terms of active agents in the governing process. These insights problematize the idea of allocating 'authority' to one or a few actors in a system. Instead it suggests that governing is a contingent set of relationships whereby a variety of actors exert influence in historically conditioned spaces. In effect, this requires a more nuanced conceptualization of governance as a process whereby actors are taken into account in the process of creating institutions (Loconto and Fouilleux, 2013). In the next section, I draw upon advances in post-structural theories of governmentality and standards to develop a conceptual framework of how standards might assemble governance arrangements.

\section{Assembling governance}

Gibbon and Ponte (2008) proposed that the lens of governmentality might usefully problematize the outstanding questions in GVC governance of "representation and practice, and 
between interests, the complexity of situations and the contradictions of achieving multiple objectives with few tools” (p. 385). Foucault developed this framework as a way to understand the birth of liberalism (Rose et al., 2006), thus it should be no surprise that many authors are beginning to use the same framework to understand the practices of neoliberalism (e.g., Blowfield and Dolan, 2008; Djama et al., 2011).

Governmentality refers to the range of practices that "constitute, define, organize, and instrumentalize the strategies that individuals in their freedom can use in dealing with each other" (Foucault, 1997: 300). It relies upon "power [that] is exercised from innumerable points, in the interplay of non-egalitarian and mobile relations" (Foucault, 1977: 94). Governmentality thus allows us to see power as the "outcome of collective actions exercised through networks of associations" (Cheshire and Lawrence, 2005: 36). In this way we can recognize the diversity of authorities that have the capacity to govern different spaces according to different objectives. This recognition of diversity opens up questions as to "Who governs what? According to what logics? With what techniques? Toward what ends?” (Rose et al., 2006: 85)

The above questions are similar to those that have been taken up by the sociology of standards to understand how standards exert a form of 'anonymous authority' (Busch, 2000, 2011; Timmermans and Epstein, 2010). Here, standards are considered more than rules for organizing and regulating markets, rather they are socio-technical devices that are used to discipline and govern humans, things and the processes that bring the two together (Busch, 2000). In order for standards to exert this governing power, infrastructures must be put into place, which facilitate interactions between actors. These are systems of standards-setting, certification, accreditation, and support services (Busch, 2011; Loconto and Busch, 2010). These systems are interlocking networks of oversight where the power of standards is seen when the interactions run smoothly, rather than being embodied in specific actors (Callon, 1992). Alternatively, standards can work to make some interactions invisible precisely because they become part of other processes where alternative devices and actors are more important (Loconto, 2014).

In the case of sustainability standards, these networks are still in the process of being constructed and have not yet become institutions in their own right (Hatanaka et al., 2012). Therefore, we cannot talk about standards as governance instruments or technologies as if they were already artefacts or apparatus in the Foucauldian sense. Rather, the governmentality of 
conduct through standards is achieved through the creation of loose and mobile networks that can bring people, objectives and technologies into alignment (Djama et al., 2011; Miller and Rose, 1990). Put differently, voluntary standards are mechanisms that facilitate the emergence of agencements, which are the collectives of human beings, technical devices, scientific tests, and written standards that are embedded in institutions, conventions, personal relationships and groups (Callon et al., 2002). Indeed, this notion has emerged in the geography, material anthropology and international relations literature in the form of the term assemblage (Braun, 2006; McFarlane, 2009; Murray Li, 2007; Ong and Collier, 2005). “An assemblage is the product of multiple determinations that are not reducible to a single logic” (Ong and Collier, 2005: 12). Here assemblages are used to refer to emerging spaces of interaction and consist of multiple material and discursive relationships. These scholars use the term assemblage to enable the analysis of politics and changing forms of authority (McFarlane, 2009; Sassen, 2006). I adopt the French term agencement because it maintains the root of the word 'agency' which Delueze and Guattari (1987) argue is not allocated individually to specific actors, but to the dynamic that emerges when the members of the group act together.

This concept tries to capture the dialogical and dynamic nature of institution-building as it is through the organizing of actors that the resulting collective has the capacity for action. In other words, agencements are temporarily stabilized collectives that assemble the social for the achievement of specific objectives or to raise matters of concern (Callon and Rabeharisoa, 2008; Latour, 2005). We can compare this concept to Cleaver's (2002) notion of institutional bricolage where there is an element of improvisation and pragmatism, where unexpected consequences contribute to the institution building process. Alternatively, we might characterize it in terms of Millers's (2003) idea of 'the virtual moment', which looks at how instances of the practice of government and economics perform consequences that are not necessarily the intentions of the actors. In both instances, we must recognize that agencements are temporary passage points where actions take place on the road towards the construction of institutions. It is because they are a part of an institution-building process that they have governing power, which is not necessarily tied to a specific distant actor or logic, but is highly dependent on local social interactions.

Thus, if we analyze the activities of standards in this way, as the ability of distant actors to govern local actions based on how they construct an agencement, we can logically proceed to 
reframe Rose's questions as follows: how is an agencement constructed, by whom, with what techniques, and for what objectives? These precise questions about the agencements that we observe in action enable us to answer the broader questions posed by governmentality scholars specifically how the various activities that are necessary for the implementation of standards (e.g., financing, training, service delivery) translate into the ability of distant actors to govern producers' local activities. Empirically exploring these agencements in the local contexts where standards touch down will provide greater insights into the tenuous nature of governing at a distance.

\section{HISTORY OF TEA IN TANZANIA}

In order to understand how current agencements take form, we must understand the historical context that contributes to how and why tea producers act 'responsibly' in their local contexts, which influences the extent to which these actions can be governed by distant actors. Tea is a priority crop for Tanzania and the fifth largest export crop after cotton, coffee, cashew nut and tobacco. Total annual production amounts to about 32 million kilograms, about 90 percent of which is exported earning around \$37 million in foreign exchange (TBT, 2009). FAO (2009) characterized the Tanzanian policy for large scale farming as ambivalent, but the tea sector is different as it is historically one of the leading industries in plantation agriculture and investment by foreign companies. There is also a current move towards greater cooperation by investors with smallholder farmers. Today, the tea sector in Tanzania is fully privatized and the land area (total 22,721 ha) is divided between the estate sector (>200 ha, company-owned) and the outgrower sector (<200 ha, farmer-owned). ${ }^{3}$ The outgrower sector includes medium-scale farmers with average tea holdings of 16 ha and small-scale farmers with an average 0.37 ha (Priest, 2010). ${ }^{4}$ Tanzania has 27,142 outgrowers cultivating 9,884 ha (Priest, 2010). Only the smallest producers farm their land entirely with family labor, and many smallholders employ workers, often on a casual basis. The largest growing areas are found in the Southern Highlands region of Iringa and Mbeya provinces and in the Usambaras of Tanga province. In 2010, the tea

\footnotetext{
${ }^{3}$ Both medium-scale ( $>1$ ha) farmers and small-scale ( $<1$ ha) farmers are considered by the Tea Board of Tanzania to be part of the smallholder sector as the characterization of an estate is based on the business model, rather than on the number of hectares.

${ }^{4}$ Three year average (2006-2009).
} 
sub-sector consisted of nineteen made tea $(\mathrm{MT})^{5}$ processing factories owned by eleven companies and three smallholder associations, and five licensed blending and packing factories (TBT, 2009).

The number of people that depend on tea related activities for their livelihoods is vast (e.g., producers, agents, transporters, extension officers). In Tanzania, approximately 20,000 people are employed by the tea sub-sector while 32,000 smallholders receive commercial income from tea (TBT, 2009). It was estimated that the local rural economy benefited by about $\$ 15$ million (Ndunguru, 2001). The industry also provides rural social facilities such as dispensaries, day care centers, schools and hospitals as well as local goods and services. An employee of an international blender explained the history of the sector like this:

You have got to remember the history of why these things happened in the first place. At the time when these plantations were put in in India, and in East Africa, it was the colonial times in effect. There was no infrastructure, so basically the plantations became the infrastructure and the town council, and the hospital and maintained the roads and in a lot of places they still have a legal obligation to do that. So it's not building on nothing; it's building on a history where private business was always expected to do that (...) If you want to have a reputation as a good employer its part of the benefits package. It has benefits for the business as well; it is not just for the government in that they don't need to pay for a school.

In other words, the construction of tea communities and infrastructure in Tanzania is founded in the colonial economic model. Independence from British protectorate rule was gained in 1961 and beginning in 1967, with the Arusha Declaration, a period of socialist political and economic governance ensued. President Julius Nyerere focused political and economic attention on self-reliance and protectionism. This led to the adoption of policies that sought to encourage the evolution of an egalitarian society based on state-ownership of the major means of production including corporations. During this period many of the colonial tea plantations were nationalized and run in the same ‘colonial' manner by the Tanzanian Tea Authority (TTA) on behalf of the citizens. The TTA focused on encouraging smallholder production (which was illegal prior to the 1960s); however, the TTA was largely unproductive and heavily indebted by the 1980s. In line with the neoliberal agenda for the privatization of agriculture in Africa, the government of Tanzania (GoT) tried to revive the sector in the early 1980s by privatizing and

\footnotetext{
${ }^{5}$ Made tea is the technical term used to refer to tea that emerges from the factory post-fermentation and drying. This tea is ready for consumption.
} 
rehabilitating two tea estates which had been nationalized in the 1970s; restructuring the Tea Board; privatizing the six state-owned tea factories; and revamping public research on tea. Full privatization of the tea industry was reached with the Tea Act of 1997.

Political uncertainty plays an important role in shaping interactions among stakeholders in the tea sector. The national government has a history of both nationalizing productive infrastructure and "government interference" in business affairs (Simbua, 2006). As a result, there exists a certain level of ‘cautious awareness’ by private multinational corporations and local investors who own the majority of the processing infrastructure in the Tanzanian tea industry. One of the responses to this uncertainty has been to involve smallholders as shareholders in these factories. This move was mandatory for the privatized state owned factories whereby the government reserved 25 per cent of the shares for smallholders. This remains the policy for new factories, however, to date, only three of the nineteen factories are currently coowned by smallholder associations. ${ }^{6}$ In other words, while the majority of shares belong to private or foreign investors, the factories are co-owned by local smallholder farmers whose interests are taken into consideration, which helps to prevent direct involvement by the state.

Simbua (2006) argues that the share of the tea crop processed from smallholders is another stabilizing factor against political uncertainty for tea processing factories. One MNC absorbs up to 23 per cent of its factory capacity from smallholders. Such commitment and reliance by the factory on smallholders, who in turn must receive their payment on time, helps to protect the company against possible state intervention - which remains a fear expressed by private companies in my interviews. Another tea company absorbs only five per cent of the crop it processes from smallholders, thus this security is not ensured. However, the large-scale job provision in their estates, which provides livelihoods to thousands of families in Mufindi district, and the second payments that the company provides to its limited out-growers earn the company the support of both the government and surrounding communities. ${ }^{7}$ As a result of these strategies, and the neoliberal policies promoted by the government more generally, recent direct state intervention in tea production has been very limited. Nonetheless, the threat still conditions how private companies interact with outgrowers and government officials and is manifested by

\footnotetext{
${ }^{6}$ Interview with Tea Board of Tanzania, 24 March 2014.

${ }^{7}$ Interview with Unilever, 26 March 2014.
} 
the 'responsibilities' that tea producers take on in local context. This explains why the following agencements are open to the influence of distant actors.

\section{ASSEMBLING GOVERNING AT A DISTANCE}

In this section I describe three agencements that I identified in the Tanzanian tea sector. In order to identify the traces of governmentality, I focus on understanding who the actors are; how each standard works as a socio-technical device; and what the objectives are for each particular situation. I will describe how it is through the construction of these collectives, particularly how finance and services are provided, that standards enable distant actors to govern producers' local actions. These cases were selected based on the coding of qualitative data about the responsibilities of tea companies in local contexts. ${ }^{8}$ These data were derived from interviews and focus groups with certified and non-certified actors in Tanzania. Given the high level of cross-certification in the industry, some of the companies are involved in more than one agencement.

\section{Premium funding of public services}

The most consistently discussed aspect of voluntary standards was its role in providing a premium and what could or could not be completed using these funds. Out of the four standards (ETP, FLO, OR, and RA), only the FLO standard provided money (an extra US\$ 0.50/kg of MT) that was specifically designated for use by tea producers (both certified estates (HL) and small farmers (SPO) ${ }^{9}$ to invest in the local communities (the social premium). In the hired labor situation, a 'sustainability margin' was added to the FLO premium to encourage factories to participate in the system. The 'sustainability margin' is a payment of $0.10 \$ / \mathrm{Kg}$ out of the 0.50 $\$ / \mathrm{Kg}$ social premium that goes to the estate management only to support improvements in working conditions as part of on-going certification and compliance with FLO standards (FLO International 2010b). As of 2010, there were no FLO certified factories that were sourcing purely

\footnotetext{
${ }^{8}$ Using grounded theory I conducted an iterative multi-stage coding process starting with a list of open codes grouped first under the categories of responsibility (17) and perception of how the standards work (37). Through axial coding I compared the data across these codes to group them according to the three agencements where there was a relationship between a responsibility (i.e., community, corporate strategy, philanthropy) and a function of the standard (i.e., premium funds, public goods, market access, no change in practice).

${ }^{9} \mathrm{HL}$ stands for Hired Labour, which is the Fairtrade Labelling Organization's (FLO) standard for farms that hire labour, while SPO means Small Producer Organizations and its corresponding FLO standard.
} 
from SPOs; therefore we have two clear paths for FLO premiums, either estates (4) were certified or SPOs (1) were certified.

Since the FLO premium fund is provided to both small farmer associations and hired employees at estates, both groups are enrolled in the handling of these funds. The most common use for these funds is to build classrooms in public schools, to provide greater access to water for the villages of workers or small farmers, build bridges or repair roads, and build dispensaries and provide other health services in rural areas. Table 1 provides an illustration of the utilization of these funds from the one FLO premium fund. Many of these services are considered pubic in that once they have been constructed, there is rarely a usage-charge placed on them (with regards to roads and water). The school buildings effectively become part of the State infrastructure as the addition of classrooms means that the government will have to send more teachers to the district. ${ }^{10}$ While citizens must always pay school and dispensary fees throughout Tanzania, those paid at the structures built with FLO funds are assessed at the state-established rate rather than at a privately calculated rate.

\section{[Insert Table 1 about here]}

During the focus groups with estate and factory workers, the role of the FLO premium was discussed in relation to the tea company's actions towards its stakeholders (defined as employees, communities, families, contractors (small farmers), shareholders, government, and the environment). How the FLO premium facilitated this relationship is best articulated by the following excerpt from the focus group discussion.

It helps the company, for example getting money from FLO; we built a public school, it helped because the students study there. Going on from this, our dispensary has been expanded, therefore there are civilians from the outside that come and are treated here. Therefore the government has been helped in terms of the buildings and with the staff that the government perhaps may not have been able to provide. They have been accustomed with the company therefore the government has been helped and as we said, these workers are paid; the company pays taxes and workers. And from them, the children that are born to the workers

\footnotetext{
10 There were a number of contestations around the Fairtrade rule prohibiting workers to build schools on company property; since if they build on company property the physical buildings would be considered private property rather than public property. Both workers and management were frustrated with this as it meant that the already existing company schools could not be improved with Fairtrade funds and often the distances from where workers lived to the government schools is too great for their children to attend those schools.
} 
get a good life. Government helps them, it absolves tribal differences [through education], and it teaches them here. Therefore, in general, it has improved the living standard of the community.

Reciprocity between actors was a common theme and the notion that FLO funds provide relief towards the onus on the company to fulfil its community operations was also expressed with regards to small farmers. An auditor explained it as follows:

All the farmers are using the funds for community development - for schools. In Tanzania for instance, the government would require the farmers to contribute to build a second classroom. But with the premiums, they would use the premiums; which means there is something that is economically empowering them to better contribute to the community.

In other words, in the Tanzanian context, both individual farmers and companies are expected to contribute to the construction and maintenance of public services. This is a hallmark feature of the cooperative public services delivery model used in Tanzania since the 1980s, whereby the government relies heavily on contributions from private enterprises and 'citizenconsumers' to pay for the provision of public services (Njunwa, 2007). When interviewing the district commissioner of a tea producing district, I asked:

A1: Does FLO relieve some of the burden on the local government?

DC: No. We need a diversity of strategies, we all need to contribute. The tea companies have been very active in this area for a long time. Now farmers are able to contribute also. Every extra help is good for the district.

The ability of private and civic actors to better contribute to the community was facilitated by changes in the governance of the FLO premium.

Before two years ago, the standard required that there actually be a restriction on how to use [the premium], but now they have changed. Annual meetings will decide how to use it. If they [farmers] decide that now we have problems with individual families, then they can decide to divide the amount amongst the farmers. But with the hired labor that is not allowed, they must make community contributions. I think that the way that the standard has given this loophole now is good for the farmers.

The revision of the rules regarding the use of the FLO premium funds, providing more flexibility for producers, allows both farmers and companies to fulfill their obligations with greater ease. This flexibility was found to be an important feature of this agencement as it meant that farmers 
and farm workers were better able to decide what community contributions they wanted to make, and to be recognized for them by the government. Makita (2012) describes the allocation of FLO premiums as a patron-client relationship, where the estate (patron) provides goods and services to its stakeholders (clients) in order to ensure the compliance of clients with the patrons interests. Thinking of this relationship as an agencement and not solely as a two-way relationship illustrates how the FLO standard and its premium contribute to the ability of distant actors (FLO) to govern local processes (through their rules about the use of their funds) that are situated in the interactions between local actors (farmers, district government and private companies).

\section{Mobilizing value chain funding for capacity building}

A second agencement is the emerging role of standards development organizations (SDO) joining other actors in tea value chains as providers of technical assistance and donors of 'development' or 'capacity building' projects that focus on the social and environmental goals of the standards that they have created. Each of the standards networks found in Tanzania is involved in this type of activity.

The first example comes from the FLO network and is well illustrated by the Adapt to Climate Change (AdapCC) project funded by Cafédirect and GIZ (Deutsche Gesellschaft für Internationale Zusammenarbeit). The project brought together Cafédirect's coffee and tea producer members from around the world to conduct risk assessments for adaptation to Climate Change. Cafédirect has been sourcing directly from FLO certified factories in Tanzania since 1998 and the two companies that are part if this network participated in the project workshops. However, this project was not focused solely on the FLO standard, as one of my research participants explained:

'our business model definitely goes much beyond the FT minimum!! (...) What I would like to stress however in line with above that this initiative (as a publicprivate-partnership with GTZ/ Germany) is precisely not [a] FLO Value Chain but a specific Cafédirect value chain and understanding of what a responsible and ethical business should do nowadays' (personal communication, emphasis in original).

In other words, while the Cafédirect value chain represents a network of FLO certified actors, the standard is only one device (in addition to technical assistance projects and an inclusive business model ) that assembles the activities of the agencements (Davies et al., 2010). 
In this particular case, the network was brought together to determine ways in which producers could make their operations and communities more resilient to climate change. One such challenge identified by the Tanzanian group was land degradation, which might be countered with reforestation. ${ }^{11}$ One of the same participants has proposed in another context that company take over the management of the nearby state-managed timber forest so to have access to a sustainable fuel-wood supply for the tea factory (Rowland, 2008). This is an issue of local contestation as the government is not yet ready to privatize the productive forests that it manages, which is part of the socialist legacy of the country. In other words, Tanzanian value chain actors were mobilizing their compliance with the FLO standard, not for its premium, as in the last example, but rather as an organizing mechanism to find other funding and support that might enable them to engage in the private management of public forest resources.

The second project concerns the Unilever/RA partnership. Unilever is a major actor in the Tanzanian tea industry, owning three factories and five estates. Unilever and the RA are collaborating beyond the simple certification of the company's estates. The RA (2009) noted in a 2009 press release that 'Unilever-Lipton is also helping to conserve the flora and fauna that thrive in and around its farms through various conservation initiatives, such as a project in Tanzania, a biodiversity hotspot' (p. 3). This project was funded through the Critical Ecosystem Partnership Fund (CEPF), which is a joint initiative of Conservation International, the Global Environment Facility, the Government of Japan, the John D. and Catherine T. MacArthur Foundation and the World Bank. The purpose of this project was to 'Analyse the causes of forest degradation around the Mufindi Tea estate. Based upon this, and in conjunction with select user communities, develop projects to promote alternative sources of energy and agroforestry practices to supply fuel wood, building materials, and medicinal plants as a means to conserve these forests’ (CEPF, 2007: 17-18). The RA proposed a similar project involving other companies in Tanzania in 2009 and had plans for training smallholders in the Southern Highlands of Tanzania on sustainable agriculture practices in preparation for RA certification. ${ }^{12}$ The policy of the RA in this regard is to provide a complete package for certified producers, which includes training and conservation activities that allow the producers to better comply

11 Participant observation in the AdapCC workshop in Nairobi, 26 November 2009.

${ }^{12}$ Personal communication with company manager in November 2009 and interview with a RA employee in June 2010. 
with the RA standards. Despite this policy, the RA does not have the funds to cover these activities, so they seek external donor funds (including participation fees from private companies) to finance their training and conservation projects (Rainforest Alliance, 2011). ${ }^{13}$ This example shows how the standard is again used as leverage for pulling together funds and stakeholders into projects that go beyond mere compliance with the standard.

Indeed, what we see in both of the above examples is the inclusion of distant private and civic actors (donors, NGOs, Blenders - but not necessarily the SDOs) into a local hybrid arrangement (an agencement) where farmers and tea companies are managing environmental resources. Through these projects, what the local actors manage is governed by these distant actors through the projects that create financial and conceptual boundaries around what can be managed in the local context.

The third example originates in the organic network and consists of a relationship between a specific buyer and a specific producer. One of the largest organic and FLO specialty blenders in Germany buys tea directly from an estate in northern Tanzania. The blender is also an agent of the company that markets Tanzanian tea, which is an India-based company that manages all of the sales of its Tanzanian estate tea from its Indian office. In addition to purchasing under both the organic and FLO labels, the blender provides technical assistance on quality standards. This consists of an organic agriculture specialist on retainer that visits the estate routinely and provides advice on organic practices, as the blender explained: 'he is employed by us, he is an Indian, wherever he goes our projects get free consulting. ${ }^{, 14}$ This practice of providing consulting advice is also accompanied by additional development projects whereby the buyer contributes to forwarding organic practices, empowering producers, and providing social services. The website explains how this is done:

Fair prices, high quality tea, and exceptional standards for organic tea cultivation [are] hallmarks of this partnership. [Activities include] the inclusion of the producers in the marketing process, creating a system of maximum transparency, both for customers and for the producer. The certification of producer groups by the standards of fair trade (FLO) opens up the possibility of the teas with the Fair Trade logo to market and provide additional funds for the development of these disadvantaged regions (Cha Dô, 2011).

\footnotetext{
${ }^{13}$ Interview with RA employees in November 2009 and in June 2010.

${ }^{14}$ Interview with blender in May 2010
} 
Put differently, the blender in this agencement is investing his private financial resources and interests with the FLO premium to provide public services - such as agricultural extension to an estate and its workers. In this case, the standards are used by the blender to create an agencement that governs how agricultural practices (organic) are taught to farm workers and the types of community investments (FLO) that are made.

Finally, the ETP is focused on providing capacity building to its members as it is in the process of transforming the nature of its organization (ETP, 2009). The ETP developed its teaspecific standard from the Ethical Trade Initiative base standard. The way by which producers and other value chain actors interact is slightly different from the other standards as the ETP is a member-based organization where these members are the European blenders rather than a variety of private and public sector stakeholders as is seen in the organic, FLO, and RA networks. As such, the 'monitoring' (or certification audits) of the producing estates and factories are paid by the members making participation by producers virtually free (yet also obligatory and without any perceived benefit). ${ }^{15}$ When it transitioned from a monitoring organization to a capacity building one in 2010, ETP modified its activities toward assisting producers to become certified against RA, FLO and UTZ certifications (ETP, 2010). Here, the ETP standard works as a device to construct an agencement with value chain actors and other SDOs that will build the capacity of producers to comply with RA and FLO standards. In both of these last two examples we again see distant actors controlling local practices - but in these cases it is through the knowledge that is being used to train farmers in practices through the provision of services.

In all of these instances, we see how the standards schemes function as agencements that bring value chain actors together in additional activities that support compliance with the standards by producers. However, these are not obligatory parts of the standards compliance process and would often be missed during a certification audit, which is often considered to be the way through which standards govern (cf. Bernstein and Cashore, 2007). It seems that the opportunities for collaboration in projects that go beyond compliance are important for agencements to emerge as this is how standards are made relevant in local contexts (cf. Ouma, 2010). We see this reflected in the rhetoric within the ISEAL Alliance ${ }^{16}$ as standards are increasingly referred to as 'standards' systems where certification is considered as only one part

\footnotetext{
${ }^{15}$ This was a consistent comment made by all ETP monitored producers that I interviewed in Tanzania.

${ }^{16}$ The global membership association for sustainability standards
} 
of a broader system of training and support services (ISEAL, 2013). This aspect of the agencement clearly shows the governance effects of standards where they are more than just rules that need to be followed. In these instances we see how the 'beyond compliance' activities encourage value chain actors to make their own investments in local activities that further the objectives of the local communities but also the social and environmental goals of the SDOs.

\section{Mobilizing Donor Funds to green the industry}

The final agencement relates to the history of Tanzanian tea companies in gaining access to donor-funded development projects that are not related to their certification status - yet allow them to meet the requirements of certification, thus drawing the standards into existing collectives. In this section I draw on the example of a program that relates to the environmental requirements of the ethical, FLO, and RA standards. Attention to the environmental aspects of the business deal mostly with those projects revolving around renewable energy, which are mentioned in the standards, but are not considered to be 'minimum requirements' or 'major nonconformities'.

The push towards finding renewable sources of energy is related to the requirements for energy in the processing phase of tea production. On average, a tea processing factory produces between 198-205 kgs of MT from one cubic meter of fuel wood. The use of fuel wood for tea processing has been a subject of fierce criticism from environmentalists in the past. The process initially involved harvesting natural forests hence causing significant environmental damage. However, the tea industry in Tanzania responded to this challenge by developing a self-sufficient renewable source of fuel wood through forestry programs (Unilever, 2003). In addition to fuel wood, most factories in Tanzania rely on electricity from the National grid. However, an East African Tea Trade Association (EATTA) survey in 2004 found that $11 \%$ of tea factories in Tanzania were completely off-grid and depended entirely on diesel generators for their power (GEF, 2007: 7).

As a result of energy pressures, the use of renewable energies for the processing of tea in East Africa is rising. The Greening the Tea Industry in East Africa (GTIEA) project is a small hydro-power initiative that was approved by the Global Environmental Facility (GEF) Council for funding as a full-sized project in 2007. It is co-implemented by the United Nations Environment Program (UNEP) and the African Development Bank (AfDB) and executed by East 
African Tea Trade Association (EATTA) to co-fund the development of hydro-power sites by tea companies in tea growing areas to decrease the tea factories' overdependence on the main grid. The objective of the proposed small hydro-power $(0.2 \mathrm{MW}-5 \mathrm{MW})$ project is to reduce electrical energy use in tea processing factories in member countries while increasing power supply reliability and reducing Greenhouse Gas emissions. The Suma hydro project is being invested in by the Wakulima Tea Company in Rungwe as part of this larger tea industry project (GTIEA, 2009).

Separately, two small hydro-power projects exist in the Southern Highlands, both associated with Mufindi Tea Company (MTC). The Roman Catholic Diocese of Njombe was also included in a World Bank project to build a small hydro-power project at Indonja Falls of the Ruhudji River. 'The project proposes to supply power to the Catholic mission at Kilocha, ${ }^{17}$ plus the villages of Ihanga, Itupila, Kifanya, and Iboya. Excess power will be sold to Tanzania Electrical Supply Company Ltd. (TANESCO)’ (World Bank, 2007: 54). A separate Mwenga hydro rural electrification project is also underway in Mufindi and is being implemented by MTC. This site is on the MTC estate, and is located approximately $55 \mathrm{~km}$ from the MTC headquarters. 'Power is now proposed to be supplied to MTC, Unilever, villages along [the] transmission route, and supply of power to TANESCO under the proposed standardized PPA and Tariffs' (World Bank, 2007: 54). The progress made at Mwenga is summarized in the company’s 2009 Annual Report:

The Standard Power Purchase Agreement with TANESCO has been finalized and will be executed shortly (...) Positive steps have been made to make connections to rural users at a heavily subsidized rate via the Rural Energy Fund, and the distinct possibility that Mwenga Hydro can sell Certified Emission Reductions on the international market. (Lafferty, 2010)

In the Southern Highlands the push towards developing small hydro projects is both an innovation for expanding rural electrification in the communities surrounding the tea factories, as well as a means for the businesses to conserve both expenses and fuel. The original idea for these small hydro-power projects actually emerged from what some of the old colonial companies did. Since the tea companies were established in areas that were uninhabited forests more than 100

\footnotetext{
${ }^{17}$ The Catholic mission at Kilocha planted more than 150 hectares of tea and are currently selling their tea to MTC. At the time of writing they had begun the Fairtrade certification process and had secured a commitment by MTC to build a processing factory.
} 
years ago, out of necessity, the tea estates became isolated self-sufficient communities. For example, the Dindira Tea Factory in the Usambara area of Tanzania installed a $250 \mathrm{~kW}$ small hydro-power plant to power its tea factory. While in Kenya in 2008, I toured the original Brooke Bond small hydro-power plant built in Kericho in the 1930s. This is still operational today and served as the model for the GTIEA project. The project document presents the following evidence to support their proposal: 'Unilever with a total installed capacity of $2 \mathrm{MW}$ is reportedly making savings of the order of Kshs 44 million (US\$ 600,000) on electricity costs per year' (GEF, 2007: 10).

In the standards, there is no binding requirement for businesses to invest in alternative sources of energy. Rather, the innovative use of these technologies reflects the pragmatic approaches that many of the companies in Tanzania have taken to resolving both economic and environmental constraints to their businesses and as an added bonus, they count towards compliance with some of the more rigorous environmental indicators of the standards. In this sense, the agencements are created through local private companies and international donors and are extended to include standards in order to receive credit for achieving ongoing objectives. Therefore, it seems that SDOs are profiting from the pragmatism of tea companies in Tanzania, who have a history of mobilizing international donor funds to make improvements for environmental requirements, which help them to meet both local and global objectives.

\section{CONCLUSIONS: REASSEMBLING GOVERNANCE}

The premise of this article was to understand how standards govern at a distance in specific locales. I argue that standards are used to do this not by being implemented as rules as much as by facilitating the emergence of agencements, or governance arrangements, that permit both distant and local actors to articulate and govern local situations. By examining how the agencements are constructed and the interactions that occur within them, I illustrated how governance is done by distant actors in specific locales. Specifically, I presented an agencement constructed by producers, tea companies, local government officials, and FLO that used FLO premiums for the purpose of providing public community services. I explained that in this agencement the flexibility incorporated into the standard enabled more actors to participate in the provision of local public services. In the value chain agencement I explored the variety of ways that distant blenders collaborated with distant SDOs in capacity building projects that contributed 
to producers' ability to meet FLO, OR and RA standards' environmental objectives. Finally, I explained how the experience of local tea companies in mobilizing international donor funds brought together an agencement around environmental concerns that were not part of SDO-led initiatives, but enabled the companies to comply with standards nonetheless. All of these examples show that despite the stated purpose of the agencement, distant actors are able to influence the ability of producers to act 'responsibly' in their local contexts. This assertion brings to light a few insights into the phenomenon of 'governing by standards'.

First, these agencements include a number of actors who are not often seen as participating in either 'private regulation' or in local public action. As illustrated above, the nature of public-private partnerships (PPP) in Tanzania is a combination of the historically entrenched systems of colonialism and socialism, and the neoliberal approaches to development assistance. The legacy of these policy regimes is a tea industry that is both required by law to provide certain services to its employees and also expected by those citizens living in the surrounding communities to provide these services. McNeill and St. Clair (2011) argue that 'multilateral organizations are "response-able", in the sense that they are uniquely placed to act by virtue of the powers that we, the people of the world, have given them: economic resources, expertise, and the political legitimacy they enjoy by virtue of their mandates' (p.1). However, this ability to respond in the case of Tanzania is hindered by a number of local resource constraints and political uncertainties, which affect local companies, MNCs and the district level governments alike. It is at this nexus where tea companies are enrolling multiple voluntary standards and their networks to assist in their provision of community services. These case studies further show that in these PPPs the State is primarily represented by any number of northern states, which play the role of a donor working together with international and local private companies within a development policy of PPPs, rather than representing dialogue and negotiation between the Tanzanian State and local and international private companies. While a District Commissioner insisted that this use of private funds to provide public goods is needed and is not necessarily indicative of the failure of the Tanzanian State - 'we need a diversity of strategies ${ }^{18}$ she claimed - it is indicative of the ability of private governmentality to influence public action. Indeed, it is the opportunity to engage multiple standards in agencements that

\footnotetext{
${ }^{18}$ Interview with district commissioner November 2009.
} 
provides these private and public sector actors the flexibility to realize local public services. This also explains why we see such a strong focus on the mobilization of funds as a core feature of these agencements. In other words, the agencements provide a local space for distant actors to use standards to govern the types of community assistance provided, the capacity building available and compliance with environmental indicators.

Second, these examples illustrate the pragmatics of governance. While my cases do show that some uses of voluntary standards enforce values (e.g., social, economic and environmental sustainability) that are based on neoliberal notions of political economy (Blowfield and Dolan, 2008), they are also more often being used pragmatically by local and value chain actors to serve their own interests. Therefore, it would not be correct to say that actors use standards to purposefully create agencements, as one might do when they refer to the emergence of private regulation as an authoritative implementation of rules (cf. Abbott and Snidal, 2009). Rather, it seems that agencements emerge when local actors draw upon the adjacent possibilities to pursue multiple objectives (both pre-existing and emergent) at the local level. As Gibbon and Ponte (2008) highlight, there are contradictions that are inherent in trying to achieve multiple objectives with one tool. What the notion of agencement adds to their critique is that these contradictions are accommodated pragmatically, and at times strategically, in the construction of collectives as local actors rarely rely upon one tool alone to resolve their problems. What the examples in this case show is that these local actions are not in line with the standard prescriptions, but they are fostered and financed by them in order to ensure the provision of public goods at a local level and comply with global standards. This illustrates how the ability of standards to govern both values and practices are indeed co-produced through interactions with existing institutions (Neilson and Pritchard, 2009). Thus, we can return to the very notion of governmentality and argue that by focusing on the construction of the agencement, rather than on a single tool, we can see how actors 'constitute, define, organize, and instrumentalize the strategies' that they use in attempts to control distant activities.

Finally, this article also shows that governance at a distance is tenuous and temporal. Local institutions and interests are stronger than 'rules' written into standards and the differences that we see in the practice of complying with standards is not as much about locally appropriating standards (cf. Ouma, 2010), but more about how governance at a distance is permitted because it is temporarily aligned with the interests, resources and obligations of the 
local actors. When these interests disalign, the ability to govern will no longer be there. By being catalysts in the mobilization of funds and services around a specific geographic and standards context, distant actors are influencing how actors are able to act responsibly in these local contexts. Thus, the ability of the standards to stimulate the construction of agencements is how distant actors expand their influence in controlling how standards are used to influence local practices - which is not necessarily according to what is written in the standard. This study opens the door for additional research on questions of temporality and of space in transitions towards sustainability. Where are the overlaps between agencements and long lasting change towards more sustainable agricultural practices? Studying the construction of agencements might provide opportunities for studying politics of 'transitions in the making' 


\section{REFERENCES}

Abbott, K., Snidal, D., 2009. The Governance Triangle: Regulatory Standards Institutions and the Shadow of the State, in: Mattli, W., Woods, N. (Eds.), The Politics of Global Regulation. Princeton University Press, Princeton, pp. 44-88.

Alphandéry, P., Djama, M., Fortier, A., Fouilleux, E., 2012. Normaliser au nom du développement durable. Editions QUAE, Paris, pp. 39-59.

Bair, J., 2009. Frontiers of commodity chain research. Stanford University Press, Stanford, CA. Bartley, T., 2003. Certifying Forests and Factories: States, Social Movements, and the Rise of Private Regulation in the Apparel and Forest Product Fields. Politics and Society 31, 433464.

Bernstein, S., 2011. Legitimacy in intergovernmental and non-state global governance. Review of International Political Economy 18, 17-51.

Bernstein, S., Cashore, B., 2007. Can non-state global governance be legitimate? An analytical framework. Regulation \& Governance 1, 347-371.

Blowfield, M.E., Dolan, C.S., 2008. Stewards of Virtue? The Ethical Dilemma of CSR in African Agriculture. Development and Change 39, 1-23.

Bonanno, A., Constance, D., 2009. Stories of Globalization: Transnational Corporations, Resistance, and the State. Penn State Press, University Park, PA.

Braun, B., 2006. Environmental issues: global natures in the space of assemblage. Progress in Human Geography 30, 644-654.

Busch, L., 2000. The Moral Economy of Grades and Standards. Journal of Rural Studies 16, 273-283.

Busch, L., 2007. Performing the economy, performing science: from neoclassical to supply chain models in the agrifood sector. Economy and Society 36, 437-466.

Busch, L., 2011. Standards: Recipes for Reality. MIT Press, Cambridge, MA.

Büthe, T., 2010. Private Regulation in the Global Economy: A (P)Review. Business \& Politics $12,1-38$.

Callon, M., 1992. The dynamics of techno-economic networks, in: Coombs, R., Saviotti, P., Walsh, V. (Eds.), Technological Change and Company Strategies: Economic and Sociological Perspectives. Academic Press, London.

Callon, M., Méadel, C., Rabeharisoa, V., 2002. The Economy of Qualities. Economy and Society 31, 194-217.

Callon, M., Rabeharisoa, V., 2008. The Growing Engagement of Emergent Concerned Groups in Political and Economic Life. Science, Technology \& Human Values 33, 230-261.

CEPF, 2007. CEPF EACF Portfolio Summary 2007. The Critical Ecosystem Partnership Fund (CEPF), Nairobi, Kenya.

Cha Dô, 2011. Philosophy. Cha Dô, Bremen, Germany.

Cheshire, L., Lawrence, G., 2005. Re-shaping the state: Global/local networks of association and the governing of agricultural production, in: Higgins, V., Lawrence, G. (Eds.), Agricultural Governance: Globalization and the new politics of regulation. Routledge, London and New York, pp. 35-49.

Cleaver, F., 2002. Reinventing Institutions: Bricolage and the Social Embeddedness of Natural Resource Management. European Journal of Development Research 14, 11. 
Davies, I., Doherty, B., Knox, S., 2010. The Rise and Stall of a Fair Trade Pioneer: The Cafédirect Story. Journal of Business Ethics 92, 127-147.

Deleuze, G., Guattari, F., 1987. A thousand plateaus : capitalism and schizophrenia. University of Minnesota Press, Minneapolis.

Dingwerth, K., Pattberg, P., 2009. World Politics and Organizational Fields: The Case of Transnational Sustainability Governance. European Journal of International Relations 15, 707-743.

Djama, M., Fouilleux, E., Vagneron, I., 2011. Standard-setting, Certifying and Benchmarking: A Governmentality Approach to Sustainability Standards in the Agro-Food Sector, in: Ponte, S., Gibbon, P., Vestergaard, J. (Eds.), Governing Through Standards. Palgrave Macmillan, Houndmills, Basingstoke, Hampshire; New York, pp. 184-209.

Dolan, C.S., Humphrey, J., 2000. Governance and Trade in Fresh Vegetables: The Impact of UK Supermarkets on the African Horticulture Industry. Journal of Development Studies 37, 147 - 176.

ETP, 2009. Talking Tea - Issue 6, The Newsletter from the Ethical Tea Partnership for Tea Producers and other Stakeholders. The Ethical Tea Partnership, London.

ETP, 2010. Enabling change across the tea sector. Ethical Tea Partnership, London.

FAO, 2009. Agricultural Sector Reforms in Tanzania: Perspectives from within, Project Report "Strengthening National Capacity in Agricultural Trade and Trade Negotiations" (GCP/URT/056/IRE). Food and Agriculture Organization of the United Nations, Rome.

Foucault, M., 1977. Discipline and punish : the birth of the prison, 1st American ed. Pantheon Books, New York.

Foucault, M., 1997. Ethics: subjectivity and truth, in: Rabinow, P. (Ed.), The Essential Works of Michel Foucault, 1954-1984. Vol. 1. New Press, New York, pp. 87-92.

GEF, 2007. Request for CEO Endorsement under the GEF Trust Fund: Greening the Tea Industry in East Africa Project. Global Environment Facility, Washington, DC.

Gereffi, G., Humphrey, J., Sturgeon, T., 2005. The governance of global value chains. Review of International Political Economy 12, 78 - 104.

Gibbon, P., Ponte, S., 2005. Trading down: Africa, value chains, and the global economy. Temple University Press, Philadelphia, PA.

Gibbon, P., Ponte, S., 2008. Global value chains: from governance to governmentality? Economy and Society 37, 365-392.

GTIEA, 2009. Greening the Tea Industry in East Africa Project: Home. Greening the Tea Industry in East Africa Project, Mombasa.

GTZ, 2006. International Conference Proceedings, Shaping globalisation - Impacts of voluntary standards, 24 - 25 October 2006. Deutsche Gesellschaft für Technische Zusammenarbeit (GTZ), Berlin, Germany.

Hatanaka, M., Konefal, J., Constance, D., 2012. A tripartite standards regime analysis of the contested development of a sustainable agriculture standard. Agriculture and Human Values 29, 65-78.

ISEAL, 2013. Standards Systems Essentials: Good Practice in Monitoring and Evaluation, ISEAL community only blogs. ISEAL Alliance.

Islam, M.S., 2008. From pond to plate: Towards a twin-driven commodity chain in Bangladesh shrimp aquaculture. Food Policy 33, 209-223.

Lafferty, G.D., 2010. Rift Valley Holdings Annual Report 2009. Rift Valley Holdings, Harare, Zimbabwe. 
Latour, B., 2005. Reassembling the social : an introduction to actor-network-theory. Oxford University Press, Oxford ; New York.

Lockie, S., Kitto, S., 2000. Beyond the Farm Gate: Production-Consumption Networks and AgriFood Research. Sociologia Ruralis 40, 3-19.

Loconto, A., 2010. Sustainably Performed: Reconciling Global Value Chain Governance and Performativity. Journal of Rural Social Science 25, 193-225.

Loconto, A., 2014. Sustaining an Enterprise, Enacting SustainaibliTea. Science, Technology \& Human Values.

Loconto, A., Busch, L., 2010. Standards, techno-economic networks, and playing fields:

Performing the global market economy. Review of International Political Economy 17, 507 - 536.

Loconto, A., Fouilleux, E., 2013. Politics of Private Regulation: ISEAL and the shaping of transnational sustainability governance. Regulation \& Governance.

Makita, R., 2012. Fair Trade Certification: The Case of Tea Plantation Workers in India. Development Policy Review 30, 87-107.

Marsden, T., Flynn, A., Harrison, M., 2000. Consuming interests: The social provision of foods. UCL Press, London.

Mayer, F., Gereffi, G., 2010. Regulation and Economic Globalization: Prospects and Limits of Private Governance. Business \& Politics 12, 1-25.

McFarlane, C., 2009. Translocal assemblages: Space, power and social movements. Geoforum 40, 561-567.

McNeill, D., St. Clair, A.L., 2011. Poverty, Human Rights, and Global Justice: The ResponseAbility of Multilateral Organizations. Globalizations 8, 97 - 111.

Miller, D., 2003. The Virtual Moment. J. R. Anthropol. Inst. 9, 57-75.

Miller, P., Rose, N., 1990. Governing economic life. Economy and Society 19, 1-31.

Murray Li, T., 2007. Practices of assemblage and community forest management. Economy and Society 36, 263-293.

Ndunguru, B.J., 2001. The Tea Industry in Tanzania, World Tea Convention, October 17-22, 2001, Nairobi and Mombasa, Kenya.

Neilson, J., Pritchard, B., 2009. Value chain struggles: Institutions and governance in the plantation districts of South India. Wiley-Blackwell, West Sussex, UK.

Njunwa, M., 2007. Cooperative public service delivery in Tanzania: Is it contributing to social and human development? Journal of Administration \& Governace (JOAAG) 2.

Ong, A., Collier, S.J., 2005. Global Assemblages: Technology, Politics, and Ethics as Anthropological Problems. Wiley-Blackwell, Malden, MA.

Ouma, S., 2010. Global Standards, Local Realities: Private Agrifood Governance and the Restructuring of the Kenyan Horticulture Industry. Economic Geography 86, 197-222.

Ponte, S., Gibbon, P., Vestergaard, J., 2011. Governing through standards : origins, drivers and limitations. Palgrave Macmillan, Houndmills, Basingstoke, Hampshire ; New York.

Prakash, A., Potoski, M., 2006. The voluntary environmentalists: Green Clubs, ISO 14001, and voluntary environmental regulations. Cambridge University Press, Cambridge, UK.

Priest, D., 2010. Current and Potential Production of Tea in Tanzania, Report for the Chai kwa maendealeo ya Tanzania Project. Wood Family Trust and Gatsby Charitable Foundation, Dar es Salaam.

Rainbird, H., Ramirez, P., 2012. Bringing social institutions into global value chain analysis: The case of salmon farming in Chile. Work, Employment and Society 26, 789-805. 
Rainforest Alliance, 2009. Leaders in Sustainability Honored at Rainforest Alliance Gala 2009, New York.

Rainforest Alliance, 2011. Certify Your Farm: How is the program financed? Rainforest Alliance, New York.

Riisgaard, L., 2011. Towards more stringent sustainability standards? Trends in the cut flower industry. Review of African Political Economy 38, 435-453.

Rose, N., O'Malley, P., Valverde, M., 2006. Governmentality. Annual Review of Law and Social Science 2, 83-104.

Rowland, P., 2008. TATEPA and RSTGA - A Successful Privatisation in Tanzania: The Progress of Wakulima Tea Company, 9th October 2008 Presentation to H.E. President Kikwete. Wakulima Tea Company, Tukuyu, Tanzania.

Sassen, S., 2006. Territory, authority, rights : from medieval to global assemblages. Princeton University Press, Princeton, N.J.

Simbua, E.F., 2006. The Economic Sustainability of Smallholder Tea Production Systems in Tanzania, Institute of Water and Environment. Cranfield University, Silsoe.

SKASC, 2012. Toward sustainability: The roles and limitations of certification, in: (SKASC), S.C.o.t.S.-o.-K.A.o.S.a.C. (Ed.). RESOLVE, Inc., Washington, DC.

Tallontire, A., Opondo, M., Nelson, V., Martin, A., 2011. Beyond the vertical? Using value chains and governance as a framework to analyse private standards initiatives in agri-food chains. Agriculture and Human Values 28, 427-441.

Taylor, P.L., 2005. In the market but not of it: fair trade coffee and forest stewardship council certification as market-based social change. World Development 33, 129-147.

TBT, 2009. Performance of the Tea Industry in Tanzania. Tea Board of Tanzania, Dar es Salaam, TZ.

Timmermans, S., Epstein, S., 2010. A World of Standards but not a Standard World: Toward a Sociology of Standards and Standardization. Annual Review of Sociology 36, 69-89.

Unilever, 2003. Tea A Popular Beverage: Journey to a Sustainable Future.

Utting, P., 2002. Regulating Business via Multistakeholder Initiatives: A Preliminary Assessment, in: NGLS (Ed.), Voluntary approaches to corporate responsibility: readings and a resource guide. UN Non-Governmental Liaison Service, Geneva, Switzerland.

World Bank, 2007. Project Appraisal Document On A Proposed Credit In The Amount Of Sdr 66.70 Million (Us\$105 Million Equivalent) And A Proposed Grant From The Global Environment Facility Trust Fund In The Amount Of Us\$6.5 Million To The United Republic Of Tanzania For An Energy Development And Access Expansion Project. World Bank, Washington, DC. 
Table 1: Fair Trade Fund Project Summary 2002-2008

\begin{tabular}{|c|c|c|c|c|}
\hline \multirow{3}{*}{$\begin{array}{l}\text { Project Category } \\
\text { Accessibility farmers Inputs }\end{array}$} & \multicolumn{4}{|c|}{ Total } \\
\hline & \multirow{2}{*}{$\begin{array}{l}\begin{array}{l}\text { \# of } \\
\text { proje } \\
\text { cts }\end{array} \\
2 \\
\end{array}$} & \multirow{2}{*}{$\begin{array}{l}\begin{array}{l}\text { Total Costs } \\
\text { (TZS) }\end{array} \\
60,000,000 \\
\end{array}$} & \multicolumn{2}{|c|}{$\begin{array}{l}\text { Total Costs } \\
\text { (US\$) }\end{array}$} \\
\hline & & & $\$$ & $54,407.46$ \\
\hline Africa Fair Trade Network & 0 & $3,167,037$ & $\$$ & $2,871.84$ \\
\hline Bridge & 2 & $1,869,500$ & $\$$ & $1,695.25$ \\
\hline Capacity Building & 3 & $4,115,400$ & $\$$ & $3,731.81$ \\
\hline Community Health Fund & 2 & $116,785,000$ & $\$$ & $105,899.58$ \\
\hline Dispensary & 10 & $39,836,311$ & $\$$ & $36,123.21$ \\
\hline Investment Projects & 8 & $38,196,500$ & $\$$ & $34,636.24$ \\
\hline Machines & 1 & $1,100,000$ & $\$$ & 997.47 \\
\hline Nursery School & 4 & $11,069,900$ & $\$$ & $10,038.09$ \\
\hline Primary School & 116 & $297,441,200$ & $\$$ & $269,716.99$ \\
\hline SACCOS & 8 & $30,557,800$ & $\$$ & $27,709.54$ \\
\hline Secondary School & 135 & $487,832,840$ & $\$$ & $442,362.41$ \\
\hline College & 1 & $2,505,000$ & $\$$ & $2,271.51$ \\
\hline Water Projects & 23 & $120,426,550$ & $\$$ & $109,201.71$ \\
\hline TOTAL: & 315 & $1,214,903,038$ & & ,101,663.09 \\
\hline
\end{tabular}

The average exchange rate for $2002-2008$ was TZS 1,102.79= US\$1 